Bangl. J. Vet. Med. (2011). 9(1): $59-66$

\title{
EFFECTS OF CHRONIC ARSENIC TOXICITY ON THE HAEMATOLOGY AND HISTOARCHITECTURE OF FEMALE REPRODUCTIVE SYSTEM OF BLACK BENGAL GOAT
}

\author{
M. T. Islam ${ }^{1}$, S. Parvin ${ }^{2}$, M. Pervin ${ }^{2}$, A. S. M. Bari ${ }^{2}$ and M. A. H. N. A Khan ${ }^{2}$ \\ ${ }^{1}$ Department of Pathology and Parasitology, Faculty of Animal Science and Veterinary Medicine, Patuakhali \\ Science and Technology University, Khanpura, Babugonj, Barisal-8210, Bangladesh \\ ${ }^{2}$ Department of Pathology, Faculty of Veterinary Science, Bangladesh Agricultural University, \\ Mymensingh-2202, Bangladesh
}

\begin{abstract}
This study was aimed to observe the effects of chronic arsenic toxicity on the haematology and histoarchitecture of female reproductive system of black Bengal goat. Adult She goats $(\mathrm{N}=4)$ were orally administered with sodium arsenite $(4 \mathrm{mg} / \mathrm{kg}$ body weight) for first seven weeks followed by $5 \mathrm{mg} / \mathrm{kg}$ body weight for next eight weeks. Blood was collected from the treated goat at day0, 20, 40, 60, 80 and 100. There was significant difference of TEC, Hb concentration and TLC in goats which are chronically exposed with arsenic. Lymphocyte was decreased with the treatment of sodium arsenite but neutrophil, eosinophil and monocyte were increased. At the end of study the goats were euthanasized. The ovary, uterine tube, uterus, cervix and vagina were collected for gross and histopathological examinations. In histopathological examination the ovarian follicles appeared degenerated and there was much stromal thickening around the follicle. Thickened myometrial layer and shortened mucosal folds in the uterine tube were observed. There was reduction in the number and size of endometrial glands. The mucosal cell lines appeared degenerated. Thin vaginal mucosa and proliferation of connective tissue; shortened cervical crypts and thickened glandular epithelium of cervix were also observed. It may be concluded that chronic arsenic exposure might have adverse effects on the female reproductive system.
\end{abstract}

Key words: Arsenic toxicity, haematology, histoarchitecture and female reproductive organs

\section{INTRODUCTION}

Arsenic, a nonessential trace element, a potent toxin, mutagen and xenobiotic metalloid, has recently appeared as a major pollutant of drinking water in several districts of West Bengal (Saha, 1991), Bangladesh (Nickson et al., 1998), Northern Chile, Thailand, Taiwan, China, Mongolia, Mexico, Argentina, Finland and Hungary (Chappell et al., 1997). Access to safe drinking water is the basic human right. Now-a-days, one of the most serious worldwide environmental problems is drinking water polluted by arsenic. Arsenic poisoning from underground drinking water in Bangladesh was first identified in 1993 in the Nawabgonj district (Smith et al., 2000). Almost 57 of 140 million people (Mahmood, 2002) and 61 of total 64 districts of Bangladesh are reported to have dangerous levels of inorganic arsenic $(>50 \mu \mathrm{g} / \mathrm{L})$ in most of the tube wells (DPHE, BGS and MML, 1999; BAMWSP, 2001). Arsenic can enter into food chain (Ulman et al., 2004) causing wide spread distribution throughout the plant and animal kingdoms. The detection of arsenic in milk and meat is a new finding (Awal, 2007). Organic arsenic exposure can also occur by eating food. Organic arsenic is 500 times less harmful than inorganic arsenic. Inorganic arsenic trioxide is a component of geologic formations and can be washed out into the ground water. Arsenic poisoning can be related to human activities such as mining and ore smelting but is more often associated with dissolved solids naturally endemic in the aquifer environment. Chronic arsenic toxicity due to drinking of arsenic contaminated ground water is a major environmental health hazard throughout the world (Mazumder, 2008). Chronic arsenic poisoning results from drinking contaminated well water over a long period of time. This is due to arsenic contamination of aquifer water. 


\section{T. Islam and others}

Acute arsenic exposure may promote immediate gastrointestinal tract infection (Goebl et al. 1990), whereas chronic effects may exert degenerative, inflammatory and neoplastic changes of respiratory, haematopoetic, cardiovascular and nervous systems (Neiger \& Osweiler 1989). The effects may include shortened life expectancy, decrease in reproduction, and behavioural changes. In arsenic toxicosis, excitement, restlessness, ruffled hair coat, ataxia, incoordination, muscle tremor, paralysis and severe skin lesions were observed in rats following administration of arsenic trioxide @ $100 \mathrm{mg} / \mathrm{L}$ daily for 28 days (Alam, 2004). Significant $(\mathrm{P}<0.01)$ decrease in body weight, TEC, $\mathrm{Hb}$ and PCV and significant $(\mathrm{P}<0.01)$ increase in ESR, SGOT and SGPT were noticed in his findings. He also observed heavy congestion in liver, spleen, kidney and heart with severe hemorrhagic enteritis and rose-red inflammation in the stomach.

Arsenic is a recognized reproductive toxicant in humans and induces malformations. Recently arsenic intoxication in experimental animals has been found to be associated with hepatic tumors (Waalkes et al., 2003), inhibition of testicular steroidogenic function (Sarkar et al., 1991) and spermatogenesis (Sukla \& Pandey, 1984), as well as with severe metabolic disorders such as diabetes in humans (Longnecker \& Daniels, 2001, Tseng $e t$ al., 2002).

Information related to effects of chronic arsenic toxicity on hematology and female reproductive system is yet to know. Therefore, the present study was conducted to delineate the effects of chronic arsenic toxicity on haematological parameter and histoarchitecture of female reproductive organs of black Bengal goat.

\section{MATERIALS AND METHODS}

\section{Experimental goats}

A total of eight, 52 weeks old female Black Bengal Goats weighing 11-12 kg body weight were used in this study. Goats were divided into two groups: Group A $(n=4)$ and group B $(n=4)$. Goats of group B were orally administered with sodium arsenite (Merck, Germany) at the rate of $4 \mathrm{mg} / \mathrm{kg}$ body weight for seven weeks followed by $5 \mathrm{mg} / \mathrm{kg}$ body weight for another eight weeks. Goats of group A were kept as control. All goats were fed with green grasses and grain ad libitum.

\section{Haematological examinations}

Blood was collected aseptically from jugular vein of control and sodium arsenite treated goats at day $0,20,40$, 60, 80 and 100. Total Erythrocyte Count (TEC), Haemoglobin (Hb) concentration, Packed Cell Volume (PCV), Erythrocyte Sedimentation Rate (ESR), Total Leukocyte Count (TLC) and Differential Leukocyte Count (DLC) were determined by calculating mean value $\pm \mathrm{SD}$.

\section{Pathological Examinations}

Necropsy was performed on the experimental goats (Group A and Group B) after 105 days of examination. At necropsy gross tissue changes and the weight of reproductive system were also recorded. For histopathological studies all the samples were cut into pieces and then fixed in the "Bouin's fluid" (Gridley, 1960), dehydrated in a series of ascending grades of alcohol, cleared in several changes of xylene, and infiltrated with different grades of melted paraffin in the oven at $56^{\circ} \mathrm{C}$. The tissues were then embedded in paraffin and finally the sections were cut at 6- $\mu \mathrm{m}$ thickness using rotatory microtome. The sections were then stained with Hematoxylin and Eosin staining method (Luna, 1968) and a special technique, Goldner's Trichrome staining (Khan et al. 2008).

\section{Statistical analysis}

The recorded data were compiled and tabulated for statistical analysis. Analysis of variance was done with the help of computer package MSTAT. The mean differences among the treatments were determined as per Duncan's Multiple Range Test (Gomez and Gomez, 1984)

\section{RESULTS AND DICUSSION}

\section{Haematological findings}

No significant difference in the TEC (Fig 1), Hb concentration (Fig 2) and TLC (Fig 4) was observed in control goats at day $0,20,40$ and 60 of study. There was significant difference of TEC, Hb concentration and TLC in goats of Group-B which are chronically exposed with arsenic. The suppressed TEC, Hb concentration and TLC could be due to impaired function of bone marrow following chronic arsenic toxicity (Ferzand et al., 2008; Rana et al., 2008; Chinoy et al., 2004). 
Only on day 80 of study, significant decrease in PCV was observed in treated group compared to control (Fig 3). The decrease in PCV could be due to reduction of red marrow in chronically exposed animals. Significant differences in ESR were not observed in the treated groups compared to control group.

Significant increase in Neutrophil count was recorded in the treated group compared to control on day 20 (Pvalue $\leq 0.003)$ and on day $40(\mathrm{P}$-value $\leq 0.003)$ of experiment. Again neutrophil was significantly decreased in the treated group to that of control on day 80 (P-value $\leq 0.004)$ of experiment but on the day $100(\mathrm{P}$-value $\leq$ 0.005), increased significantly. The variation of neutrophilic count could be due to subclinical bacterial infection and recovery following chronic arsenic toxicity.

Eosinophil count on day 20 (P-value $\leq 0.001)$ and 40 (P-value $\leq 0.002)$ was increased significantly in the treated group compared to control. On day 60 and 80 of experiment, no significant differences were observed among the groups. On day 100, neutrophil was again increased significantly in the treated group compared to control.

Lymphocyte count was decreased significantly on day 40 (P-value $\leq 0.005)$ and 60 ( $\mathrm{P}$-value $\leq 0.187)$ in the treated group in relation to that of control. Significant increase in lymphocyte was observed in the treated group compared to control on day 80 (P-value $\leq 0.025$ ) of experiment followed by significantly decreased on day 100 $(\mathrm{P}$-value $\leq 0.006)$.

Monocyte count left unaltered throughout the experiment.

Significant differences were not observed in the treated group compared to control throughout the experiment. In the present study, lymphocyte was decreased with the treatment of sodium arsenite but neutrophil, eosinophil and monocyte were increased to compensate normal DLC. Kaur et al. (2005) reported no change in blood in respect of differential leukocyte counts at 0,45 and 90 days after sodium arsenite supplementation.

\section{$\square A($ Control) $\square B($ Treated)}

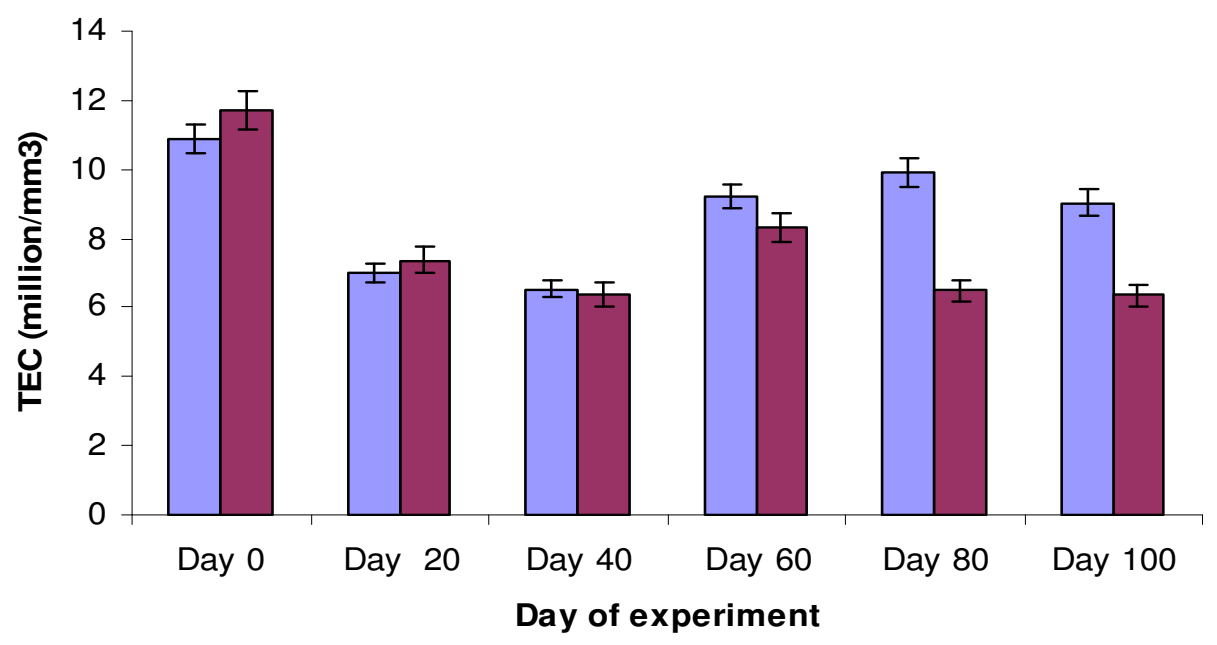

Figure 1. Total erythrocyte count (TEC) in control and sodium arsenite treated black Bengal goats at 0, 20, 40, 60, 80 and 100 days after treatment. Results are expressed as mean \pm SD. Statistically significant difference between control and treated goats are indicated by asterisks $(*, \mathrm{P}<0.05)$. 
$\square A($ Control) $\square B$ (Treated)

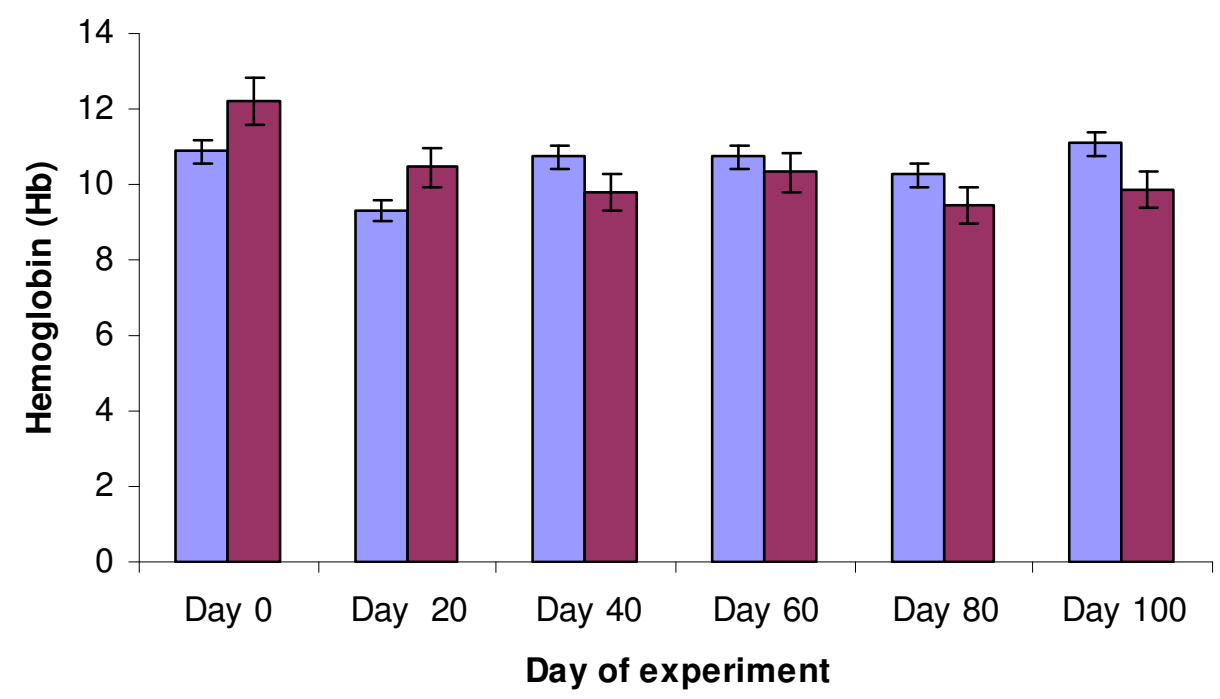

Figure 2. Haemoglobin content $(\mathrm{Hb})$ in control and sodium arsenite treated black Bengal goats at $0,20,40,60$, 80 and 100 days after treatment. Results are expressed as mean \pm SD. Statistically significant difference between control and treated goats are indicated by asterisks $(* *, \mathrm{P}<0.001)$.

$\square A($ Control) $\square B($ Treated)

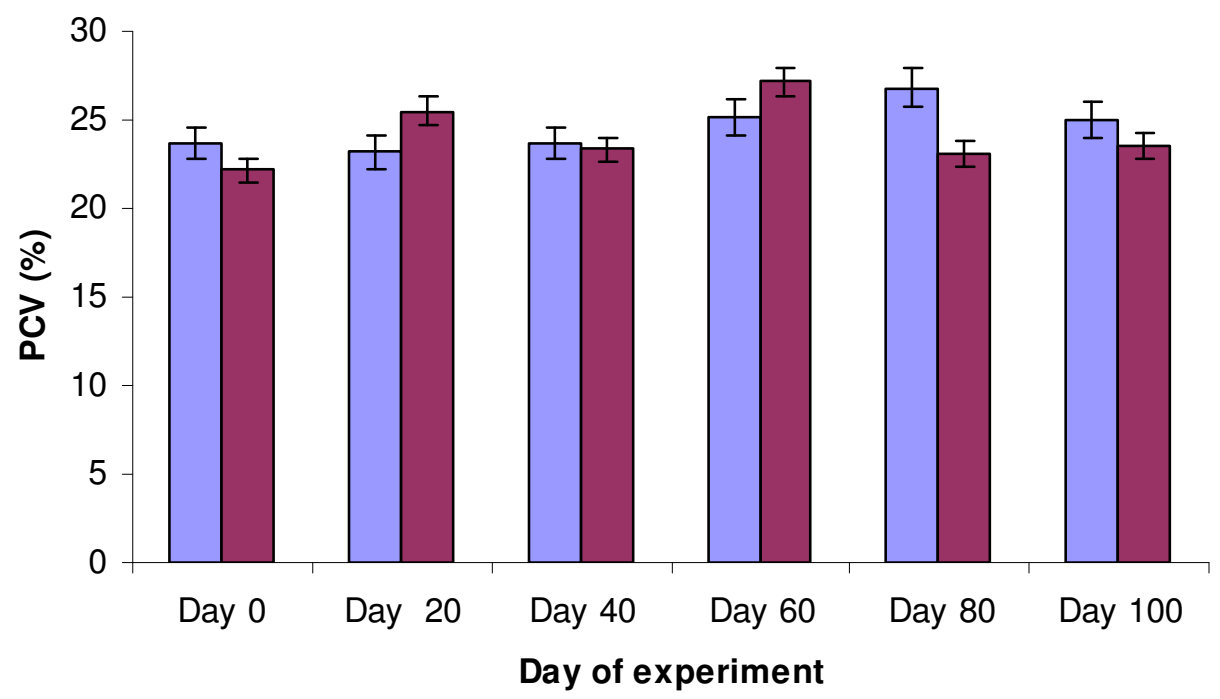

Figure 3. Packed cell volume (PCV) in control and sodium arsenite treated black Bengal goats at 0, 20, 40, 60, 80 and 100 days after treatment. Results are expressed as mean \pm SD. Statistically significant difference between control and treated goats are indicated by asterisks $(* *, \mathrm{P}<0.05)$. 


\section{$\square A($ Control) $\square B($ Treated)}

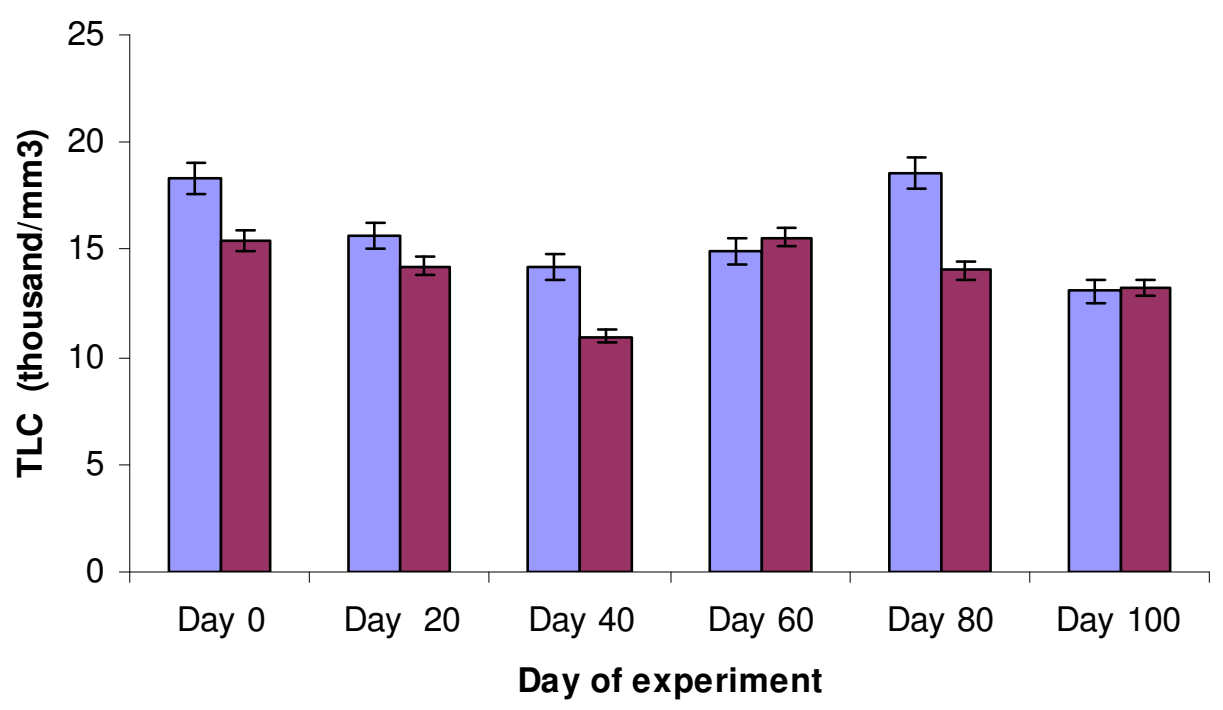

Figure 4. Total Leukocyte count (TLC) in control and sodium arsenite treated black Bengal goats at 0, 20, 40, 60,80 and 100 days after treatment. Results are expressed as mean \pm SD. Statistically significant difference between control and treated goats are indicated by asterisks $(* *, P<0.001)$.

\section{Gross Pathology}

The weight of whole reproductive organ of arsenic treated group was decreased compare to control but the weight of ovary was increased in treated group. Chattopadhyay et al. (2001 and 2003) observed significant decrease of ovarian and uterine weights after sodium arsenite treatment.

\section{Histopathology}

In histopathological examination, ovarian follicular degeneration was observed which is supported by Chattopadhyay et al. (2003), thickened muscular layer and shortened mucosal folds in the uterine tube; reduction of endometrial glands and uterine cell degeneration; In the present study, uterine cell degeneration was observed which is supported by Chattopadhyay et al. (2003). In myometrium, loosening of cells was observed and appeared similar with the findings of Akram et al. (2009). Thin vaginal mucosa and proliferation of connective tissue; shortened cervical crypts and thickened glandular epithelia of cervix were observed.
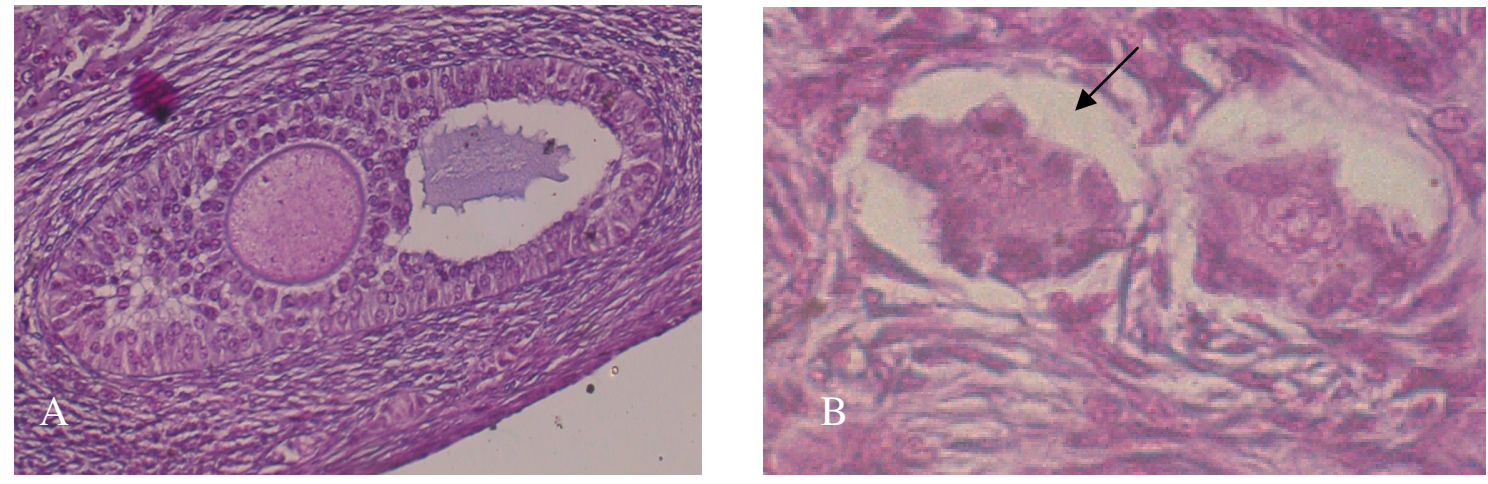

Figure 05: Section of ovary obtained from untreated goat (A) and treated goat (B) and stained with Goldner's Trichome stain. $(300 \mathrm{X})$. The ovarian follicle in the treated goat appeared degenerated and desolated (B). 


\section{T. Islam and others}
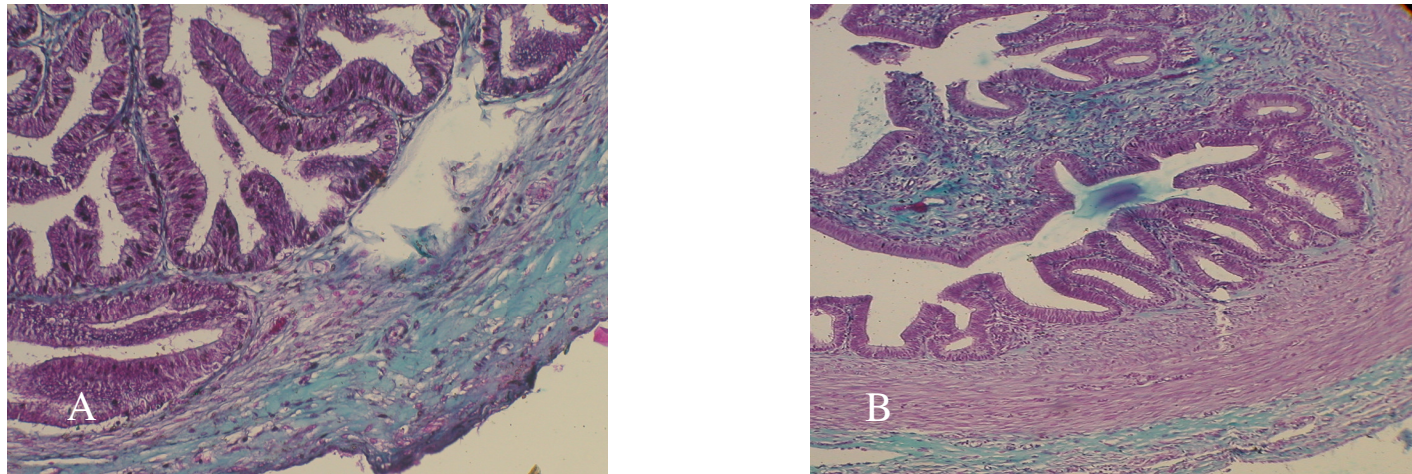

Figure 06: Section of uterine tube collected from untreated goat (A) and treated goat (B) and stained with Goldner's Trichome stain (82.5X) and the uterine tube of untreated animal showed extensive ramification of tall mucosal folds that forms an irregular lumen (A) where as in the treated animal there was thickening of muscular layer and shortening glandular epithelium (B).
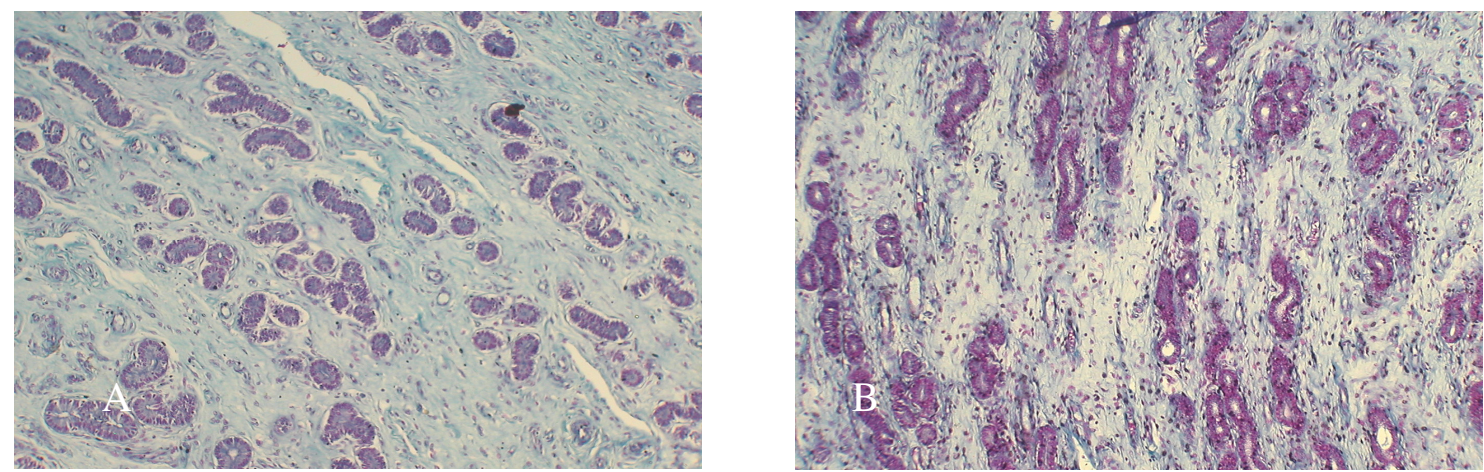

Figure 07: Section of uterus collected from control goat (A) and treated goat (B) and stained with Goldner's Trichome stain. (82.5X). The uterus of controlled goat showed large number of glands in the endometrium (A) where as in treated goats there was reduced number of glands in the endometriun and huge infiltration of reactive cells (B).
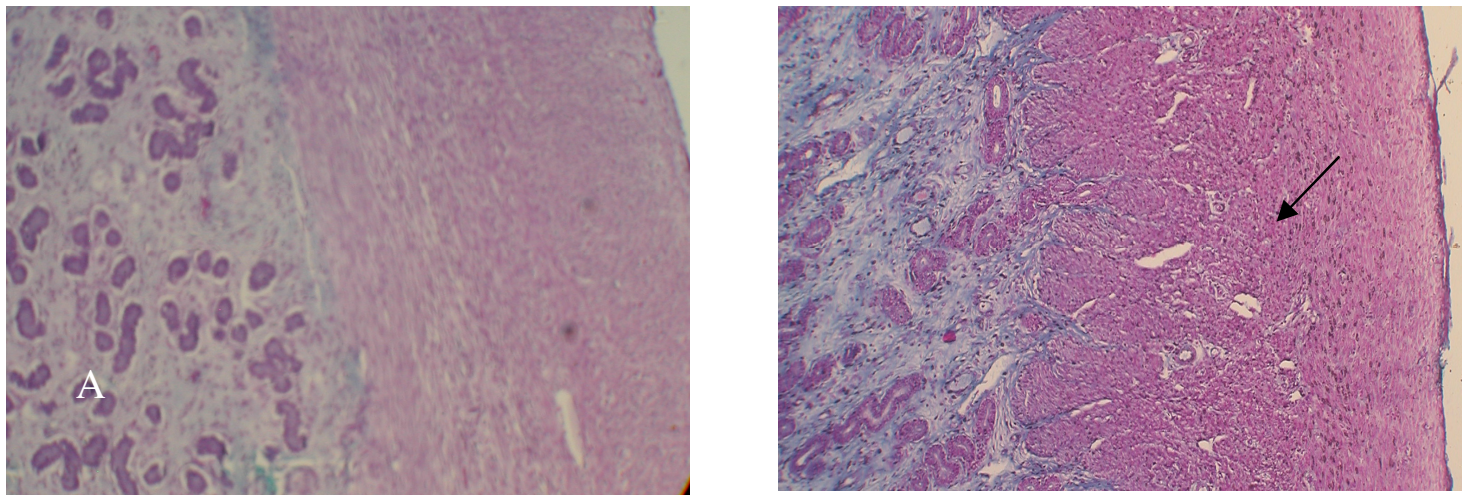

Figure 08: Section of myometrium obtained from control goat (A) and treated goat (B) and stained with Goldner's Trichome stain. (82.5X). The myometrium in the treated goat showed huge infiltration of reactive cells in the myometrium (B). 

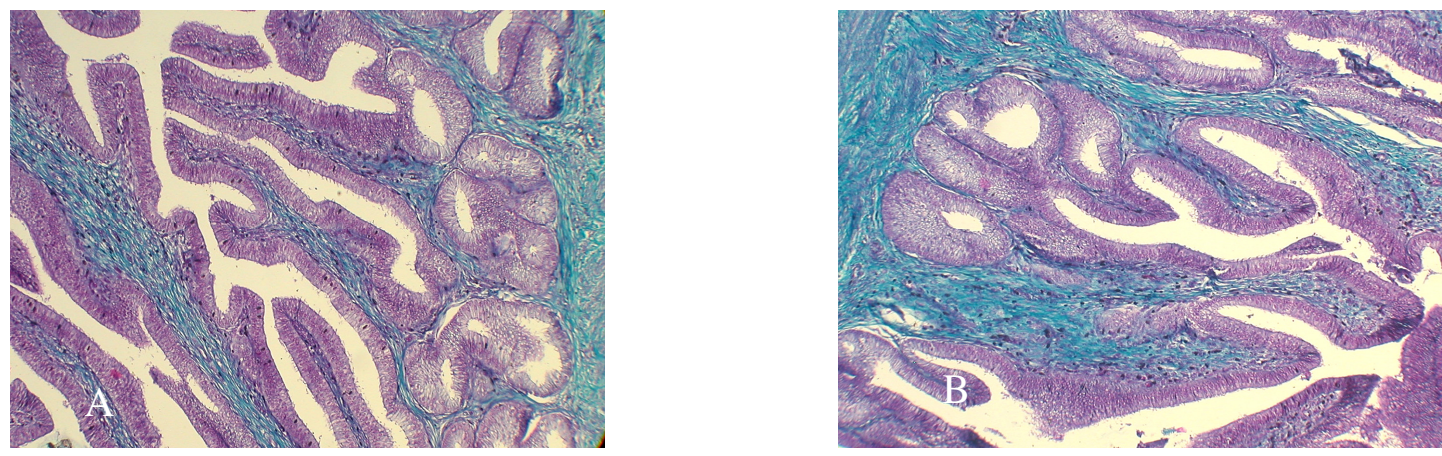

Figure 09: Section of myometrium obtained from control goat (A) and treated goat (B) and stained with Goldner's Trichome stain (10X). Controlled goat showed longitudinal folds of normal cervical crypts and the epithelium was simple columner with goblet cells (A). The treated goat showed shortening of cervical crypts and thickening of glandular epithelium (B).

The data of this study suggested that chronic arsenic exposure adversely affects the reproductive system and might be responsible for infertility. The shallow water of all most all districts of Bangladesh contain arsenic more than the maximum safety level (i.e. $0.05 \mathrm{mg} / \mathrm{L}$ water) which is alarming both for human and livestock. The findings would be helpful in assessing humans and livestock health hazard in the heavily arsenic contaminated area of Bangladesh.

\section{REFERENCES}

1. Akram Z, Jalali S, Shami SA, Ahmad L, Batool S and Kalsoom O (2009). Adverse effects of arsenic exposure on uterine function and structure in female rat. Experimental and Toxicologic Pathology 61: 415-530.

2. Alam T (2004). The role of ascorbic acid, alpha-tocopherol and ferrous sulphate on arsenic induced toxicity in long evans rats. M.S. thesis, Department of Pharmacology, Bangladesh Agricultural University, Mymensingh, Bangladesh.

3. Awal MA (2007). Detection of arsenic in the food chains and animal samples and study of the preventive measure using the best cost-effective agricultural products based spirulin against arseniasis in man and livestock. Annual Research Report (2006-2007), USDA-Bangladesh collaborative research.

4. Bangladesh Arsenic Mitigation Water Supply Project (BAMWSP) (2001). Status Report of Bangladesh Arsenic Mitigation Water Supply Project, December, 2001.

5. Chappell WR, Beck BD, Brown KG, Chaney R, Richard CC, Irgolic KJ and North DW (1997). Inorganic arsenic: A need and an opportunity to improve risk assessment. Environmental Health Perspective 105: 1060-1065.

6. Chattopadhyay S, Ghosh S, Debnath J and Ghosh D (2001). Protection of Sodium Arsenite-Induced Ovarian Toxicity by Coadministration of L-Ascorbate (Vitamin C) in Mature Wistar Strain Rat. Archives of Environmental Contamination and Toxicology. 41: 83-89.

7. Chattopadhyay S, Pal S, Ghosh D and Debnath J (2003). Effect of dietary co-administration of sodium selenite on sodium arsenite-induced ovarian and uterine disorders in mature albino rats. Toxicological Science.75: 412-422.

8. Chinoy NJ, Patel TN and Shah SD (2004). Synergistic action of vitamins and calcium in mitigation of fluoride- and arsenic-induced haematological toxicity in mice. Indian Journal of Environment and Toxicology. 14: 1-7.

9. Department of Public Health Engneering (DPHE), British Geological Survey (BGS) and Mott MacDonald Ltd (MML) (1999). Groundwater studies for arsenic contamination in Bangladesh, Final Report, Phase-I, January. EAWAG-SANDEC, 1998, SODIS News. No.3. 


\section{T. Islam and others}

10. Ferzand R, Gadahi JA, Saleha S and Ali Q (2008). Histological and haematological disturbance caused by Arsenic toxicity in mice model. Journal of Biological Science. 11: 1405-1413.

11. Goebl HH, Schmidt PF, Bohl J, Teltenborn B, Kramer G and Gutmann L (1990) Polyneuropathy due to arsenic intoxication: biopsy studies. Journal of Neurology. 49: 137-149.

12. Gomez KA and Gomez AA (1984). Duncan's Multiple Range Test. Statistical procedures for Agricultural Research. $2^{\text {nd }}$ Edi. John Wiley and Sons. pp. 207-215.

13. Gridley MF (1960). Manual of Histologic and Special Staining Technique. McGraw-Hill Book Company, New York, NY.pp . 28-29 and 82-83.

14. Kaur H, Mani V and Mishra CS (2005). Effect of arsenic on immunity, oxidative enzyme and various haematological parameters in crossbred calves. Asian-Australas.Journal of Animal Science. 18: 497-501.

15. Khan MA, Ogita K, Ferro VA, Kumasawa K, Tsutsui T and Kimura T (2008). Immunisation with a plasmid DNA vaccine encoding gonadotrophin releasing hormone (GnRH-I) and T-helper epitopes in saline suppresses rodent fertility. Vaccine. 26:1365-74.

16. Longnecker MP and Daniels JL (2001). Environmental contaminants as etiologic factors for diabetes. Environmental Health Perspectives. 6: 871-876.

17. Luna L (1968). Manual of histologic staining methods of the armed forces institute of pathology. 3rd ed. Mcgraw- hill.inc. book company, new York.

18. Mahmood SAI (2002). Arsenic is the silent killer. The Bangladesh Observer, 9th May, 2002.

19. Mazumder DNG (2008). Chronic arsenic toxicity \& human health. Indian Journal of Medical Research. 128: 436-47.

20. Neiger RD and Osweiler GD (1989). Effect of subacute low level dietary sodium arsenite on dogs. Fundamental and Applied Toxicology. 13: 439-451.

21. Nickson R, McArthur J, Burges W, Ahamed KM, Ravenserof P and Rahman M (1998). Arsenic poisoning of Bangladesh ground water. Nature. 395: 338-338.

22. Rana T, Sarkar S, Mandal TK and Batabyal S (2008). Haematobiochemical profiles of affected cattle at arsenic prone zone in Haringhata block of Nadia District of West Bengal in India. The International Journal of Hematology. 4: 32-36.

23. Saha AK (1991). Pollution in ground water in West Bengal: Final report, Steering Committee, Arsenic Investigation Project, PHE Dept., Government of West Bengal. 1-56.

24. Sarkar M, Biswas NM and Ghosh D (1991). Effect of sodium arsenite on testicular 5-3,17-HSD activities in albino rats: Dose and duration dependent responses. Medical Science and Research. 19: 789-790.

25. Smith AH, Ligas EO and Rahman M (2000). Contamination of drinking water of arsenic in Bangladesh. A public health emergency. Bulletin of World Health Organization, 78: 1093-1103.

26. Sukla JP and Pandey K (1984). Impaired spermatogenesis in arsenic-treated fresh water fish Colisa fasciatus (B1 \& Sch). Toxicology Letters. 21: 191-195.

27. Tseng CH, Tseng CP, Chiou HY, Hsueh YM, Chong CK and Chen CJ (2002). Epidemiologic evidence of diabetogenic effect of arsenic. Toxicology Letters. 133: 69-76.

28. Ulman C, Gezer S, Anal O, Tore IR and Kirca U (2004). Arsenic in human and cow's milk: a reflection of environmental pollution. Water Air Soil Pollution. 101: 411-416.

29. Waalkes MP, Ward JM, Liu J and Diwan BA (2003). Transplacental carcinogenicity of inorganic arsenic in the drinking water: induction of hepatic, ovarian, pulmonary, and adrenal tumors in mice. Toxicology and Applied Pharmacology. 186: 7-17. 